VLADO BOŽIĆ

\title{
BUŽIMSKE PODZEMNE UTVRDE
}

Vlado Božić

Braće Cvijića 17

HR 10000 Zagreb
UDK: 551.44(497.5Bužim)

Stručni članak

Ur.: 2018-11-28

Bužim je općina udaljena petnaestak kilometara sjeverozapadno od Gospića, čije se područje u literaturi spominje od 11. stoljeća. U njezinom središtu sada se nalazi gradina (ostatak utvrde) za koju nema točnih podataka kada je sagrađena, ali je poznato da su njome vladali poznati lički velikaši do dolaska Osmanlija u Liku u 16. stoljeću. Kao i drugdje u Hrvatskoj, narod se od osvajača nastojao spasiti skrivanjem u planinama i špiljama koje je radi obrane dorađivao u prave podzemne utvrde. Na području Bužima speleolozi su istražili špilju Vrbas, Špilju ispod gradine i špilju Kalvariju. Nažalost, špilje još nisu istražili povjesničari i arheolozi pa o njima zasad postoje samo podaci do kojih su došli speleolozi u svojim speleološkim istraživanjima.

Posebna zanimljivost tih špilja su građevinski zahvati u njima, odnosno gradnja zidova koji su nepoželjnim ljudima sprječavali prodor u dublji dio špilje.

Ključne riječi: Bužim, podzemne utvrde, špilja

\section{Uvod}

Današnje područje Ličko-senjske županije zauzima područje koje je u prošlosti bilo poznata kao Lika i Krbava. U središnjem dijelu županije, petnaestak kilometara sjeverozapadno od Gospića nalazi se općina Bužim, a sastoji se od više naselja: Čačić Draga, Uzelci, Tomljenovići, Šarići, Bužim, Blaževići, Došeni, Crnići, Pavičići, Serdari i Miškuljani. Područjem teče potok Bužimnica koja na krajnjem sjeverozapadu općine izvire iz špilje Vrbas i prima više manjih pritoka.

Nije poznato kako je kroz minula stoljeća to područje bilo naseljeno. Prvi pisani podaci o Bužimu potječu iz 11. st., a zatim iz 13. st. i to iz crkvenih dokumenata. O utvrdi Bužim, sagrađenoj prije dolaska Osmanlija u Liku (16. st.), nema pisanih dokaza sve do 1696. godine kada ju spominje biskup Glavinić kao utvrdu, koju je do odlaska Osmanlija s ovoga područja držao aga Zenković. ${ }^{1}$ Osmanlije su u Liku i Krbavu upadale još u 15. st. te je njihovim stanovnicima već tada bilo jasno da se sprema invazija na cijelu Liku. Iako su se nakon

1 K. MATIJEVIĆ, 2017. 


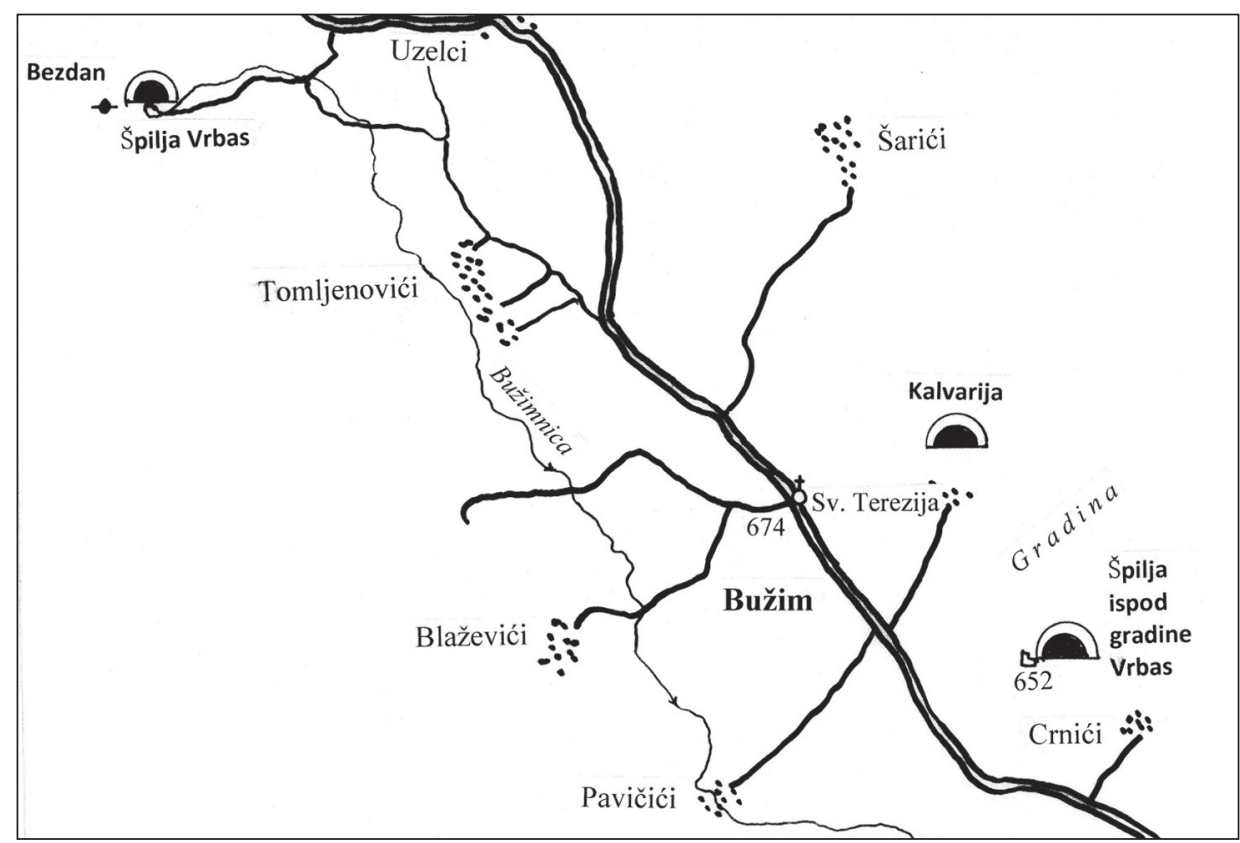

S1. 1. Nacrt bužimskih podzemnih utvrda, nacrtao: Vlado Božić

bitke na Krbavi 1493. Osmanlije povukle natrag u Bosnu, napadale su Liku i stalno pljačkale. Utvrde na području Like, a tako i utvrda Bužim, postale su meta osmanlijskih napada, pod čiju je vlast cijela Lika potpala 1527. godine. Nije poznato kako su kod toga prošli lički vladari utvrde Bužim, kojom je otada vladao aga Zenković.

\section{2. Špilja Vrbas u Bužimu}

Prvi pisani podatak o špilji dao je Dragutin Hirc još 1900. u knjizi "Lika i Plitvička jezera". Napisao je: Na vrh sela ima špilja iz koje teče potok Vrbas, kojoj vrata bijahu zazidana kamenom. Ljudi kažu, da se može unići na 400 koraka i da su prostori obzidani kamenom i požbukani mortom. I ovdje ima ljudskih kosti. ${ }^{2}$

Špilju su od 2006. do 2009. istraživali članovi društva Dinaridi - društva za istraživanja i snimanja krških fenomena (DDISKF) i posebnu su pažnju obratili na hidrologiju, o čemu su snimili i film, no zid u špilji nisu spomenuli. ${ }^{3}$

\footnotetext{
D. HIRC, 1900, 84.

3 Ž. MATAIJA, 27. 9. 2006; DDISKF, 2009.
} 


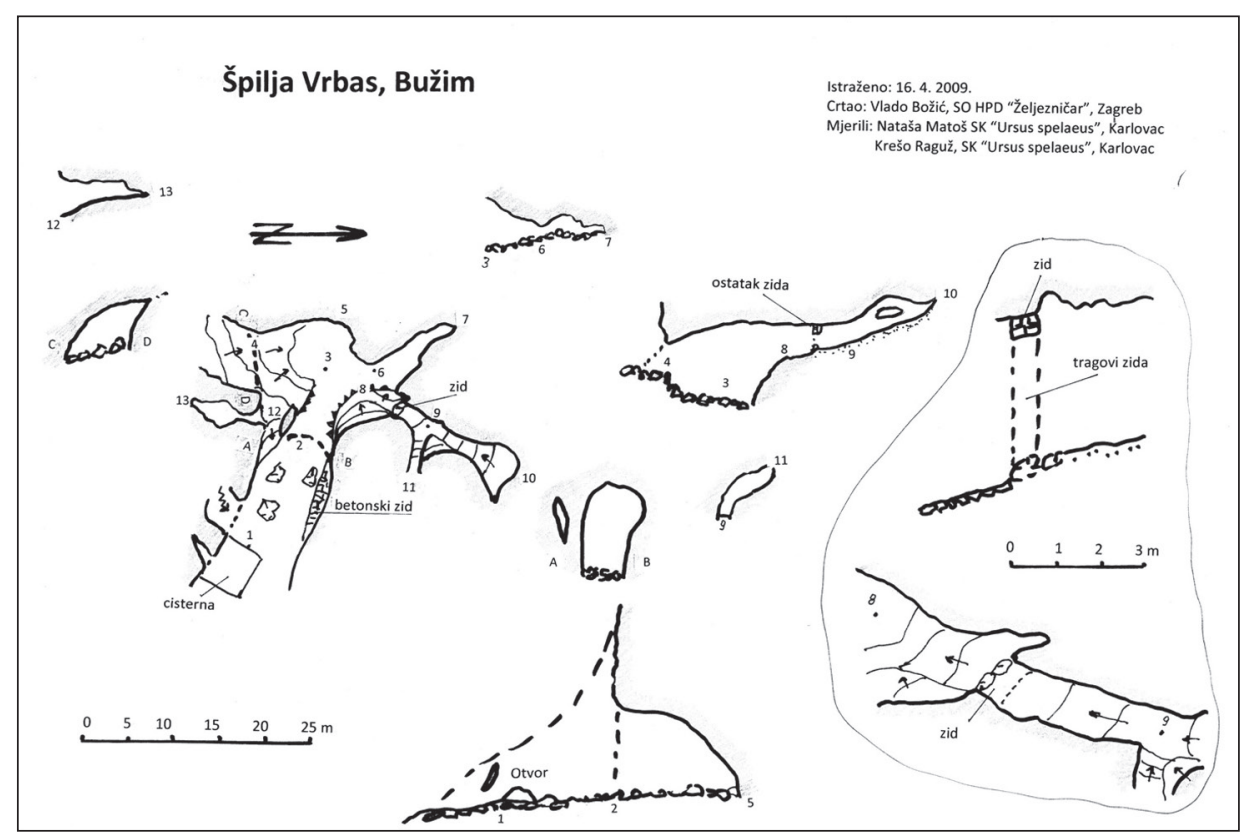

S1. 2. Nacrt špilje Vrbas u Bužimu, nacrtao: Vlado Božić

\subsection{Geografski položaj}

Špilja se nalazi u području Bužima, petnaestak kilometara sjeverozapadno od Gospića, na istočnoj padini Bužimskog bila, oko $1 \mathrm{~km}$ zapadno od zaselka Uzelci u gustoj šumi, šezdesetak metara iznad potočne doline. Iz špilje istječe potok Bužimnica, gdje je izvedena kaptaža za vodovod. Do špilje je sagrađen makadamski put iz zaselka Uzelci. Špilja je označena topografskim znakom za izvor u špilji na topografskoj karti Baške Oštarije, 1:25000, br. 419-3-4, a koordinate špilje su $X=4938720 \mathrm{~m}, \mathrm{Y}=5517936 \mathrm{~m}, \mathrm{Z}=640 \mathrm{~m}$.

Najlakši je pristup iz Gospića, u smjeru sjeverozapada prema Smiljanu do memorijalnog muzeja Nikole Tesle, zatim uskom asfaltnom cestom dalje na sjeverozapad u područje Bužima, do zadnjeg zaselka Uzelci. Kod zadnjih kuća u Uzelcima treba skrenuti na makadam u smjeru zapada, prijeći potok i livadu, a onda strmom cestom kroz šumu do izvora (od asfalta oko $600 \mathrm{~m}$ ). Taj dio ceste ide uz potok s mnoštvom slapova. Područje oko izvorišta (ima više izvora) ograđeno je žičanom ogradom s vratima na kojima je lokot. Za pristup špilji potrebno je ishoditi dozvolu lokalnih vlasti i dobiti ključ od ljudi koji održavaju vodovod (cisternu s vodom). 


\subsection{Opis špilje}

Na topografskoj karti nalazi se jedan znak za špilju i do njega (zapadno) topografski znak za jamu (jama Bezdan). Špilja ima više ulaza. Već je iz daljine uočljiv veliki glavni ulaz, širok $5 \mathrm{~m}$ i visok $9 \mathrm{~m}$, okrenut prema istoku. No, ispred njega u lijevoj stijeni nalaze se dva otvora. Prvi otvor je uska vertikalna pukotina, oko $3 \mathrm{~m}$ iznad tla, široka oko $0,5 \mathrm{~m}$ i visoka oko $2,5 \mathrm{~m}$, a nastavlja se kao uska pukotina 6-7 $\mathrm{m}$ u smjeru jugozapada.

Tri metra dalje je otvor glavnog izvora, širok $4 \mathrm{~m}$ i visok 1,5 m, iza kojeg se nastavlja niski kanal kojim dotječe voda iz smjera jugozapada. Taj su kanal istražili članovi DDISKF-a. Kod tog otvora glavni je zahvat vode za vodocrpilište sagrađeno uz izvor. Veliki glavni otvor, kojim također teče voda (povremeno presuši, a povremeno teče kao jaka bujica), nalazi se $14 \mathrm{~m}$ dalje. Lijevo od njega u stijeni je pukotinski otvor lećastog presjeka, širok $1 \mathrm{~m}$ i visok oko $3 \mathrm{~m}$, koji je spojen s velikom dvoranom iza glavnog ulaza.

Velika dvorana ima izlaz prema jugu širok $6 \mathrm{~m}$ i visok $2 \mathrm{~m}$. Vidljivo je da kad ima mnogo vode ona dotječe u veliku dvoranu kroz ovaj otvor. Tridesetak metara dalje u smjeru jugozapada nalazi se u podnožju strme stijene jamski otvor, veličine 2 x $0,5 \mathrm{~m}$ iz kojeg se čuje šum vode. Voda koja protječe kroz tu jamu istječe na glavni otvor špilje. Sigurno je da, kad u jami ima mnogo vode, ona izbija iz ovoga otvora i teče tridesetak metara površinom i ulazi u špilju te kroz nju istječe na glavni, veliki otvor špilje. Ranije spomenuti znak za jamu na topografskoj karti odnosi se na drugi jamski otvor, odnosno jamu Bezdan u kojoj također ima vode i hidrološki je vezana sa špiljom i izvorom Vrbas. Na jugoistočnom dijelu špiljske dvorane, uz bočni lećasti otvor špilje nalazi se uski kanal u smjeru juga dug $7 \mathrm{~m}$. Ova špilja s jamom zapadno od nje čini sustav s hidrološkom vezom.

$\mathrm{Na}$ suprotnoj sjevernoj strani špilje, iz sredine špiljske dvorane, vodi u razini tla mali špiljski kanal u smjeru sjeverozapada u duljini od $12 \mathrm{~m}$. S ulaza u taj kanal može se u smjeru istoka popeti oko $4 \mathrm{~m}$ visoko u kanal koji je spojen sa špiljskom dvoranom, a nastavlja se u smjeru sjeveroistoka u dužini od $17 \mathrm{~m}$. Svega $2 \mathrm{~m}$ od mjesta gdje se dolazi u taj kanal može se vidjeti ostatak zida. Kanal je tu širok samo $1 \mathrm{~m}$ i visok 2,5 m, a ostatak zida vidljiv je u stropu. Vide se dva reda kamenja povezana mortom, a na istočnoj strani kanala (ispod ostataka zida) u stijeni tragovi žbukanja s komadićima sitnog kamenja. To je dokaz da je cijeli otvor bio zazidan. Oko $4 \mathrm{~m}$ dalje na istočnoj strani kanala nalazi se strmi i uski kanal koji vodi prema površini (duljina mu je oko $5 \mathrm{~m}$ ). U kanalu iza mjesta gdje je bio zid, u tlu i na bočnim stijenama nisu pronađeni tragovi boravka ljudi. U 


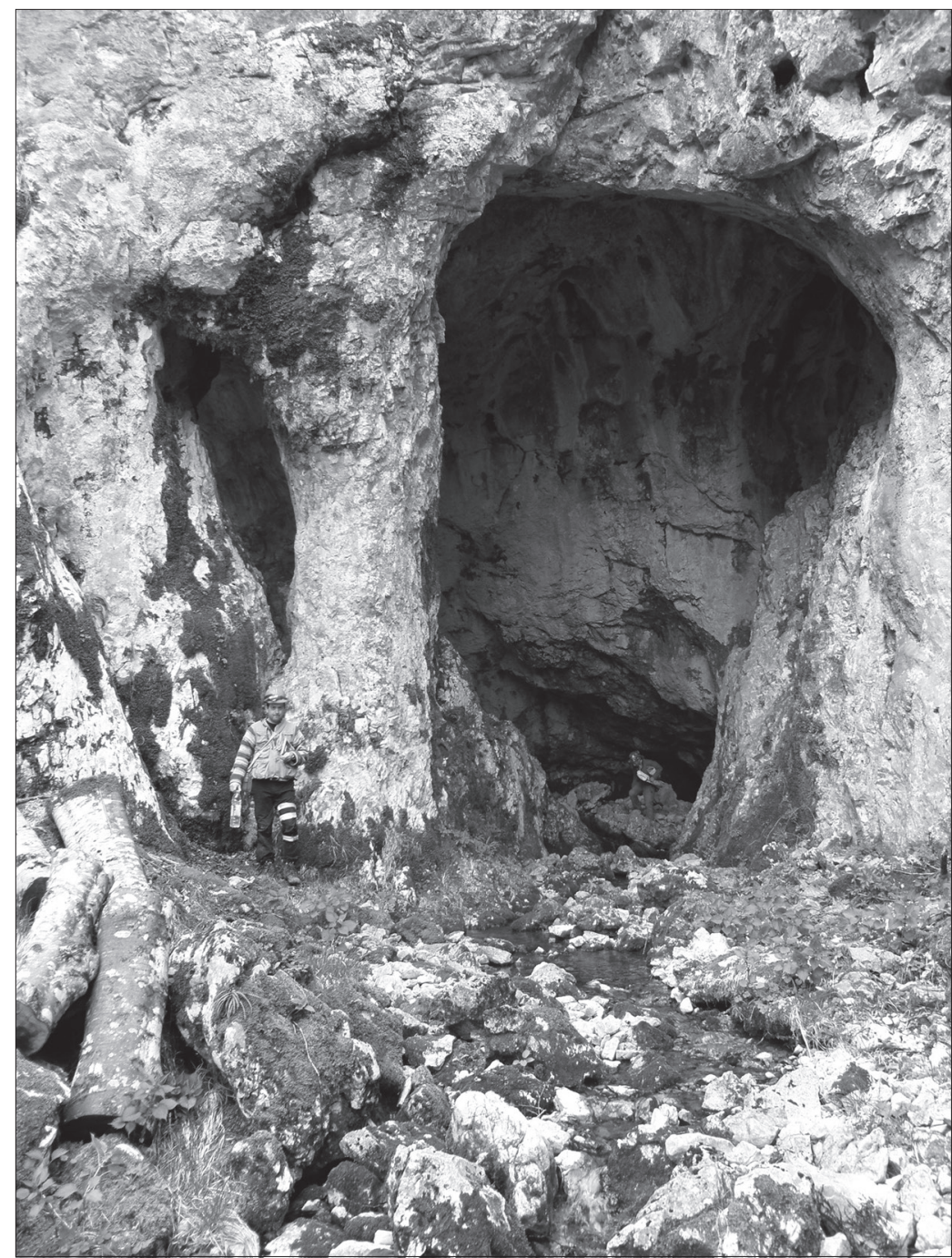

Sl. 3. Ulazni otvor špilje Vrbas, foto: Vlado Božić, 2009.

prostoru iza zida mogao je boraviti samo jedan čovjek, najviše dva. Nije poznato kada je zid sagrađen i kada je srušen.

Osim ovih tragova zida u sjevernom bočnom kanalu, nigdje u ostalim dijelovima špilje nisu nađeni tragovi zidova.

Istraživanja vodenog dijela ovog špiljskog sustava obavljali su članovi speleološke udruge DISKF-a iz Zagreba tijekom 2006., 2007. , 2008. i 2009. godine. 
Špilju su ponovno, s ciljem traženja zida, od 15. do 16. travnja 2009. istraživali Krešo Raguž i Nataša Matoš, članovi Speleološkog kluba "Ursus spelaeus" iz Karlovca i Vlado Božić, član Speleološkog odsjeka HPD "Željezničar" iz Zagreba. ${ }^{4}$

\section{Utvrda Bužim - Gradina}

\subsection{Geografski položaj}

Ostaci utvrde Bužim danas se nazivaju Gradina, a nalaze se oko $1 \mathrm{~km}$ sjeverno od zaselka Serdari i oko $300 \mathrm{~m}$ sjeverozapadno od zaselka Crnići, na stožastoj uzvisini obrasloj šumom, koja se od okolnog terena uzdiže za oko stotinu metara. Zbog šume ostaci utvrde se ne vide s ceste, koja prolazi 200 m južno od Gradine. Najlakši pristup do gradine je stazicom iz zaselka Crnići.

\subsection{Opis utvrde}

Prvi se put utvrda spominje tek 1696. godine. Prije dolaska Osmanlija u Liku utvrdom su vladali lički velikaši. U 15. st. to je bio plemić Herendić, a za vrijeme Osmanlija aga Zenković. $O$ utvrdi Bužim pisao je i naš povjesničar Ivan Kukuljević Sakcinski ${ }^{5}$ i objavio skicu (tlocrt) utvrde, zatim Većeslav Henneberg ${ }^{6}$ i Zorislav Horvat ${ }^{7}$, koji je također objavio skicu tlocrta. Objavljene skice jako se razlikuju. Obje skice predočuju četverokutni tlocrt s kružnom kulom na sjevernoj strani i oko utvrde polukružni bedem.

Utvrdu je 1900. godine opisao i Dragutin Hirc: Na obloj klisuri, $654 \mathrm{~m}$ visoko, nalazi se podor grada Bužima, kojemu nekoje zidine i danas stoje, dočim razvaljeni zidovi zapremaju pô rali zemljšta. U sredini ostaci su Herendića kule, a pod njome svodovi sa kojih odzvanja. Pod ovoma ili su podrumi, konobe ili naravne šupljine, a nedaleko kule ima i zasuta čatrnja. Starci pripovijedaju da je ovaj bunar veoma dubok, da bijaše u njemu mnogo zemljanih posuda i starih željeznih mačeva. ${ }^{8}$

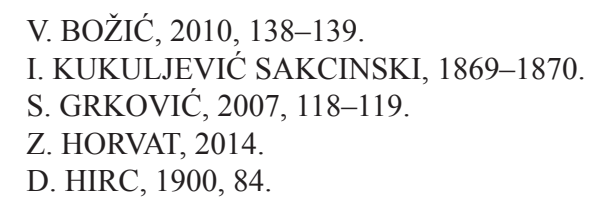




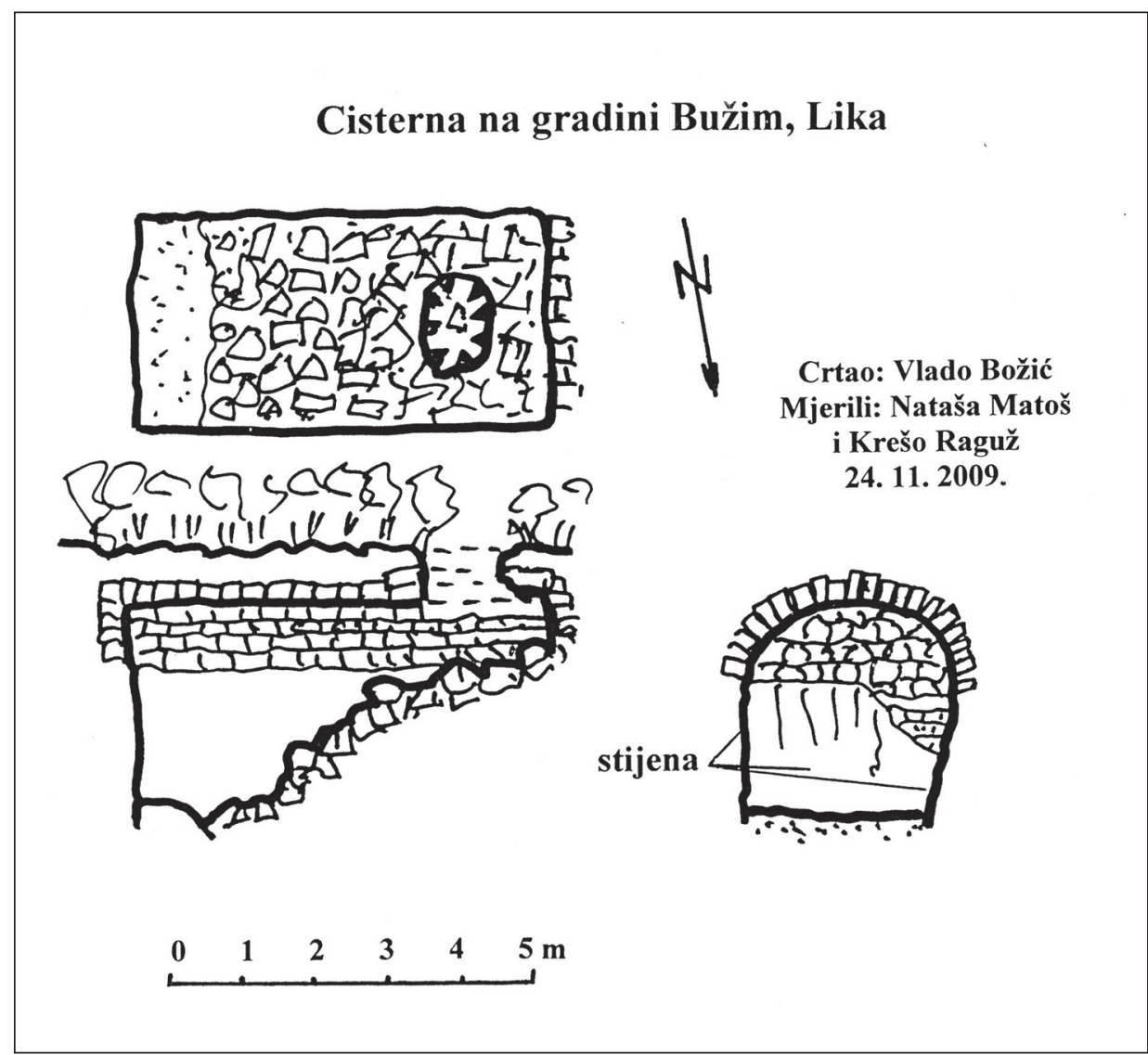

S1. 4. Nacrt Cisterne na gradini Bužim, nacrtao: Vlado Božić

\subsection{Cisterna}

Cisterna na gradini Bužim dodana je opisu špilja sa zidovima zato što se nalazi na samoj gradini i zanimljiva je jer sliči na jamu.

Na jugozapadnom dijelu gradine danas se nalazi otvor promjera 1 x 1,5 m koji izgleda kao pravi jamski otvor. To je srušeni dio stropa cisterne kroz koji se po narušenom kamenju može sići u nju.

Cisterna je pravokutnoga oblika tlocrtnih dimenzija 5,5 x 3 m i duboka ili visoka $3 \mathrm{~m}$ polukružnog svoda. Donja polovina cisterne ukopana je u živoj stijeni, a gornji dio, zajedno sa stropom, sagrađen je kamenom povezanim mortom. Po dijelu stropa hoda se po Gradini ne znajući da je to dio dobro građenog stropa. Strop je propao ili je probijen vjerojatno početkom 20. stoljeća. 


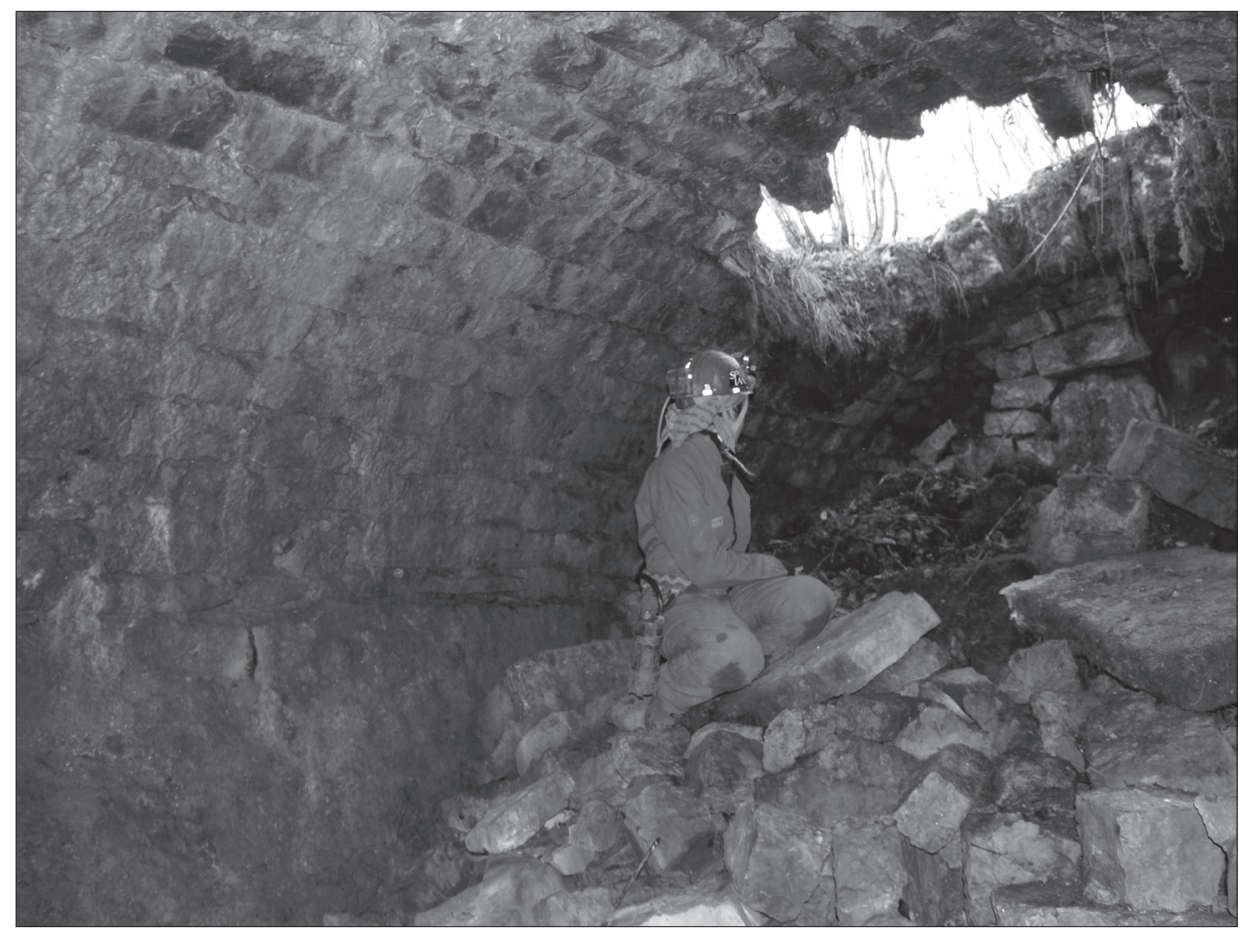

S1. 5. Unutrašnjost Cisterne na gradini Bužim - donji dio ukopan u živoj stijeni, foto: Vlado Božić, 2009.

\section{4. Špilja pod gradinom Bužim}

\subsection{Geografski položaj}

Ulaz u Špilju pod gradinom Bužim nalazi se dvadesetak metara sjeveroistočno od gradine Bužim $(652 \mathrm{~m})$ i oko $7 \mathrm{~m}$ niže od nje. Koordinate ulaza su $X=5520013, Y=4973456$ i $Z=645$. Potrebno je najprije doći na gradinu, a onda potražiti špilju.

\subsection{Opis špilje}

Otvor špilje širok je $2 \mathrm{~m}$ i visok $1 \mathrm{~m}$, a trapezastoga je presjeka. Špilja se prostire u smjeru jugozapada (u smjeru prema gradini) $20 \mathrm{~m}$, a onda u smjeru sjeveroistoka još 9 metara. Prvi dio špilje širok je oko $2 \mathrm{~m}$ i visok $1 \mathrm{~m}$. Na $5 \mathrm{~m}$ od ulaza, uz desnu stijenu špilje, vidljivi su ostaci prvog zida, a $2 \mathrm{~m}$ dalje ostaci drugoga zida uz obje stijene špilje. Desetak metara dalje špiljski se kanal malo 


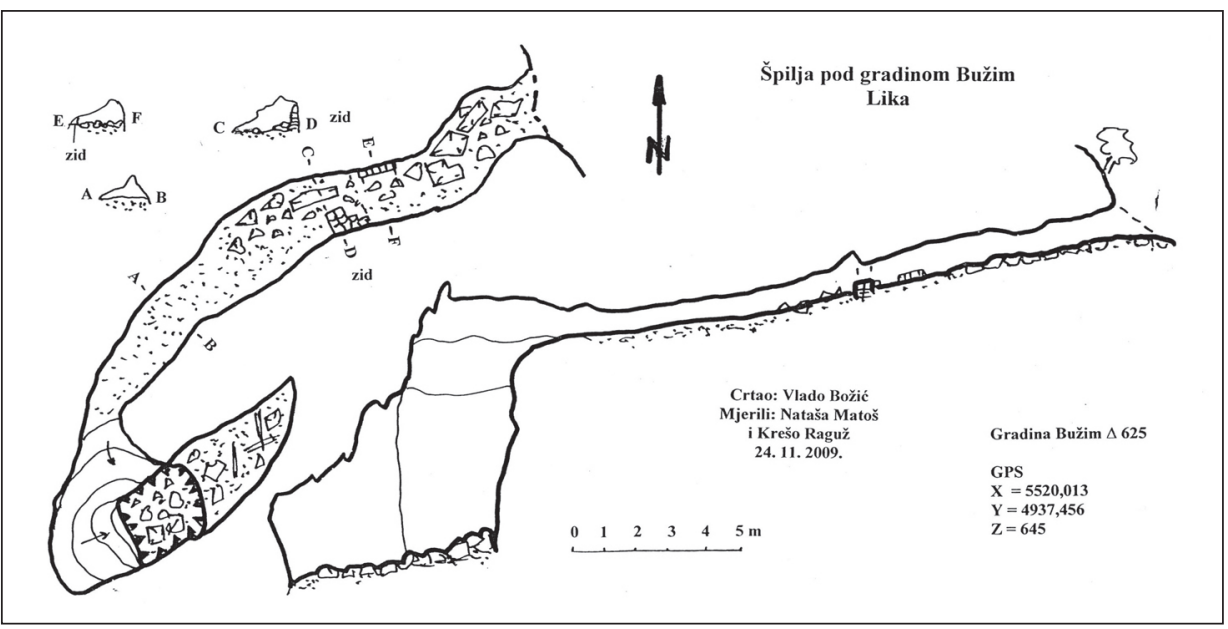

S1. 6. Nacrt Špilje pod gradinom Bužim, nacrtao: Vlado Božić

suzuje i dovodi do jame duboke $7 \mathrm{~m}$, čije dno ima veličinu 7 x 2,5 m. Stijene kanala između ulaza i jame su bez siga, dok su ljevkasti ulaz u jamu i sve stijene jame presvučene sigovinom. Dno kanala špilje od ulaza pa do zidova prekriven je kamenjem od kojih je većina bila dio zida.

Iza drugoga zida dno se sastoji od tla, pijeska i sitnog kamenja. Dno jame nalazi se 10 m niže od ulaza i prekriveno je nabacanim kamenjem (isto dijelovima zida), ali ima drvlja i smeća.

Nažalost, premalo je zidova ostalo da bi se moglo rekonstruirati izvorno stanje. Nije sigurno da je postojao zid na samom ulazu u špilju jer je kamenje oko ulaza sada vidljivo oštećeno i obraslo u mahovinu i drugo raslinje. Ova dva zida u špilji očito su bila građena kao mali labirint za prolaz te je zato bilo lako obraniti ulaz. Prema ostacima zidova može se zaključiti da su bili debeli gotovo jedan metar. U prostoru između ulaza i jame svod je tako nizak da se tu nije moglo stajati. Bilo je moguće stajati samo u jami, a za silaz do dna jame trebalo je koristiti ljestve. Špilja je mogla pružiti utočište samo nekolicini ljudi, možda jednoj malobrojnoj porodici. Tko je i kada sagradio zidove nije poznato, a također se ne zna se tko je, kada i zašto porušio zidove.

Špilju su istražili članovi DISKF-a iz Zagreba 2009. godine, a članovi SK "Ursus spelaeus" i SO HPD "Željezničar" nakon njih 24. studenoga 2009. godine zbog proučavanja zidova. ${ }^{9}$

9 V. BOŽIĆ, 2010, 138-139. 


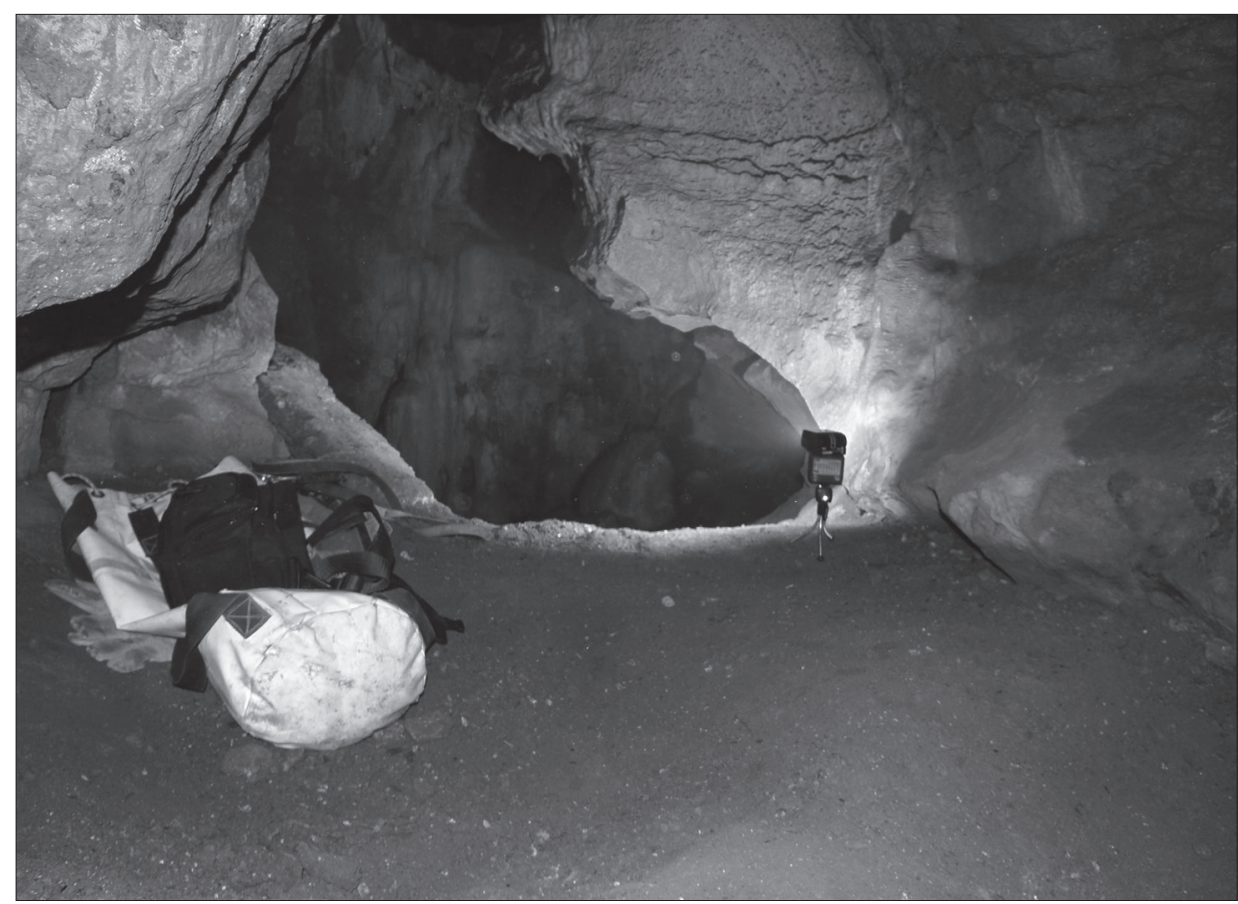

S1. 7. Otvor jame u Špilji ispod gradine Bužim, foto: Vlado Božić, 2009.

\section{5. Špilja Kalvarija ili Bužimska Kalvarija}

\subsection{Geografski položaj}

Špilja se nalazi oko 700 m sjeverno od Gradine u šumi, u podnožju brda Rupčića vrh, oko 500 m sjeveroistočno od crkve Sv. Terezije (574 m) i oko 150 $\mathrm{m}$ sjeverno od ruba livade $\mathrm{s}$ naseljem. Koordinate ulaza su $\mathrm{X}=4937958$; $\mathrm{Y}=$ 5519816 i Z $=619$.

Do nje vodi stazica koju su nedavno uredili članovi udruge "Bužimski izvori" (izvora na području Bužima ima 23), a postavili su uz cestu i ploču s osnovnim podacima o Bužimskoj Kalvariji. ${ }^{10}$

\subsection{Opis}

Ova špilja ima najzanimljiviju podzemnu utvrdu. Otvor špilje je mali, svega 1 x 1,5 m. Teško je uočljiv i okrenut je prema jugu. Kad ispred ulaza

10 D. PEROVIĆ, 3. 9. 2015. 


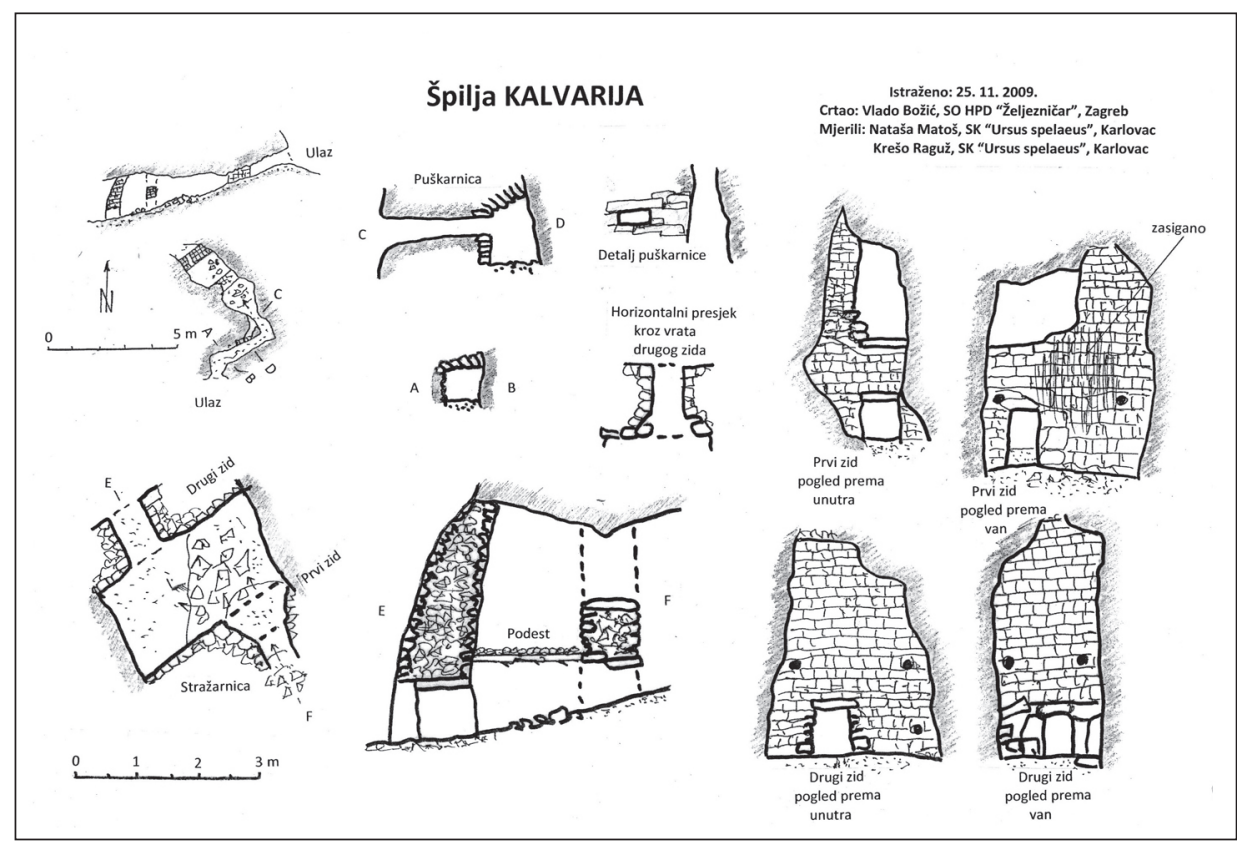

S1. 8. Nacrt špilje Kalvarija, nacrtao: Vlado Božić

izraste grm ili visoka trava, otvor se ne vidi. Špilja se od ulaza pruža u smjeru sjeverozapada u duljini od $77 \mathrm{~m}$, a najniži dio špilje nalazi se svega $6 \mathrm{~m}$ ispod razine ulaza. Od ulaza špilja se $1 \mathrm{~m}$ pruža prema sjeveru, a onda skreće u smjeru sjeveroistoka do oštrog zavoja u lijevo (pod 90) u duljini od $4 \mathrm{~m}$. Zadnja dva metra lijeve strane zida su zidana, građena kamenom i mortom. U zidu se nalazi otvor nalik puškarnici ili otvoru za promatranje onoga tko ulazi u špilju.

Špilja se nastavlja u smjeru sjeverozapada, gdje se s lijeve zapadne strane nalazi bočni otvor, tj. spoj s otvorom u građenom zidu i tako dijagonalom spaja hodnik ispred i iza zavoja. Dijelom se on nalazi u živoj stijeni, a dijelom je dograđen u bočnom zidu. Kroz taj otvor moglo se vidjeti dolazi li netko u špilju i biti nevidljiv, pa je možda služio kao osmatračnica. Cijeli taj dio špilje od ulaza pa do zida ima strop građen kamenim pločama.

Oko $6 \mathrm{~m}$ dalje od ovoga oštrog zavoja nailazi se na drugi zid. Taj zid pregrađuje cijelu špilju, koja je na tom mjestu široka svega 1,5 m i visoka oko 4 m. Ispred zida se sada nalazi kamenje i zemlja nagomilana s ulaza jer se tlo od ulaza postupno spušta do dubine od $4 \mathrm{~m}$. Pretpostavlja se da se ispod nasutoga materijala nalaze stube do zida. 


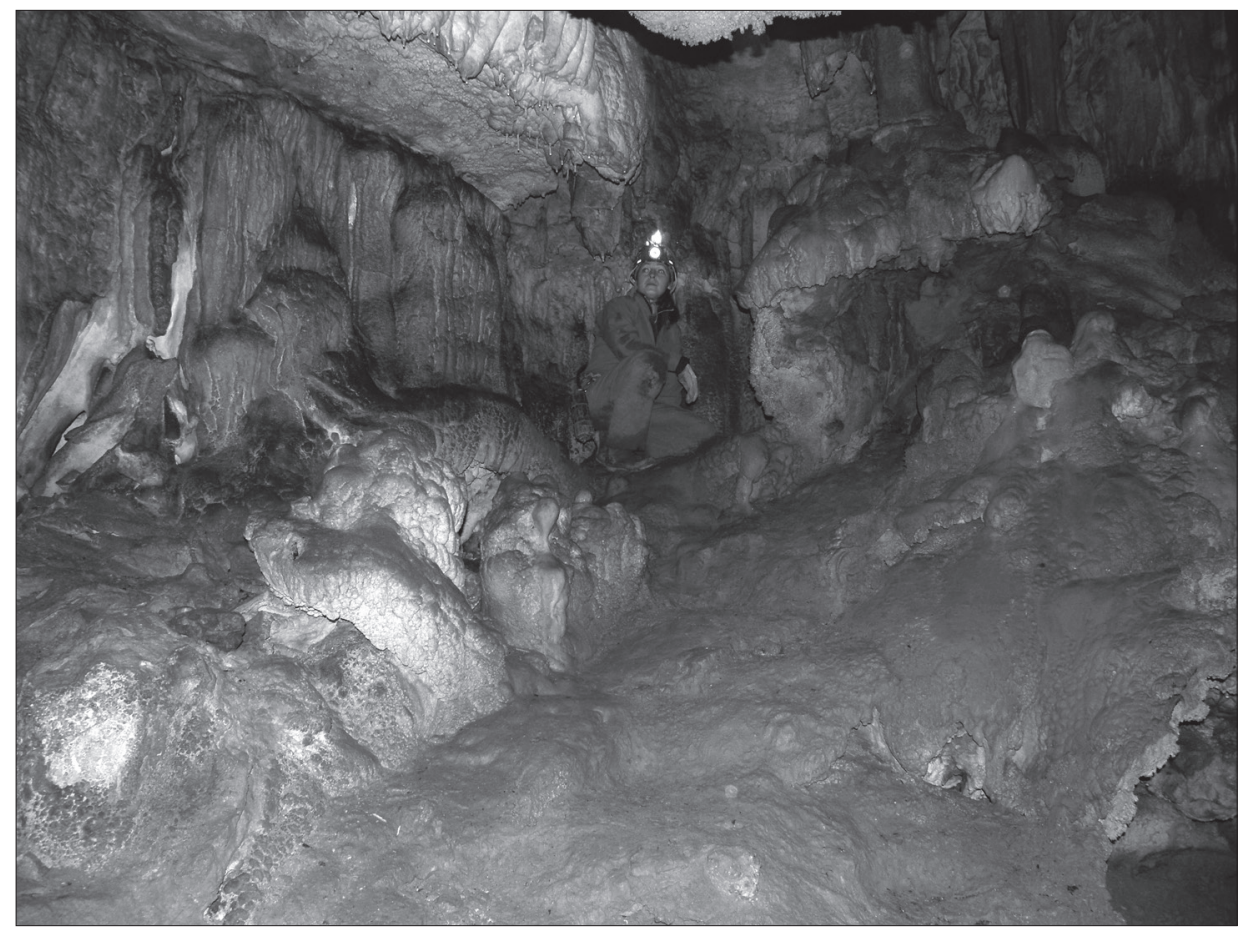

S1. 9. Iza drugog zida prostire se dio špilje Kalvarija s lijepim sigastim ukrasima, foto: Vlado Božić, 2009.

Na zidu su sada dva otvora, jedan pri dnu zida, kao glavni prolaz kroz zid, i drugi, u polovici njegove visine, sada veličine $1 \times 1,5 \mathrm{~m}$. Tu se očito nalazila puškarnica kroz koju se branio prilaz donjem otvoru. $2 \mathrm{~m}$ dalje iza toga zida nalazi se i treći zid koji s ovim drugim čini malu prostoriju široku 3 i dugu $2 \mathrm{~m}$, a visoku $4 \mathrm{~m}$. U dnu toga trećeg zida nalazi se otvor u obliku vrata veličine $0,80 \mathrm{x}$ 1,6 m, kroz koji se dalje ulazi u prirodni dio špilje. Treći zid je visok $4 \mathrm{~m}$ i širok $3 \mathrm{~m}$. Ovi pregradni zidovi debeli su $1 \mathrm{~m}$.

$\mathrm{U}$ oba ova zida vide se rupe u koje su vjerojatno trebale biti umetnute grede i na njih daske ili druge grede kako bi se stvorio podest s kojega bi bilo moguće djelovati na puškarnici na prvom zidu i braniti prilaz zidu. Ovu bismo prostoriju zato mogli nazvati "stražarnicom". Međutim, stvaranje podesta nije moguće jer zbog uskog i zavojitog ulaznog dijela špilje takve grede nije moguće donijeti do zidova. Vjerojatno su i graditelji zidova toga postali svjesni. Prema izgledu kamenih dovratnika na zidovima može se zaključiti da se otvor vrata 


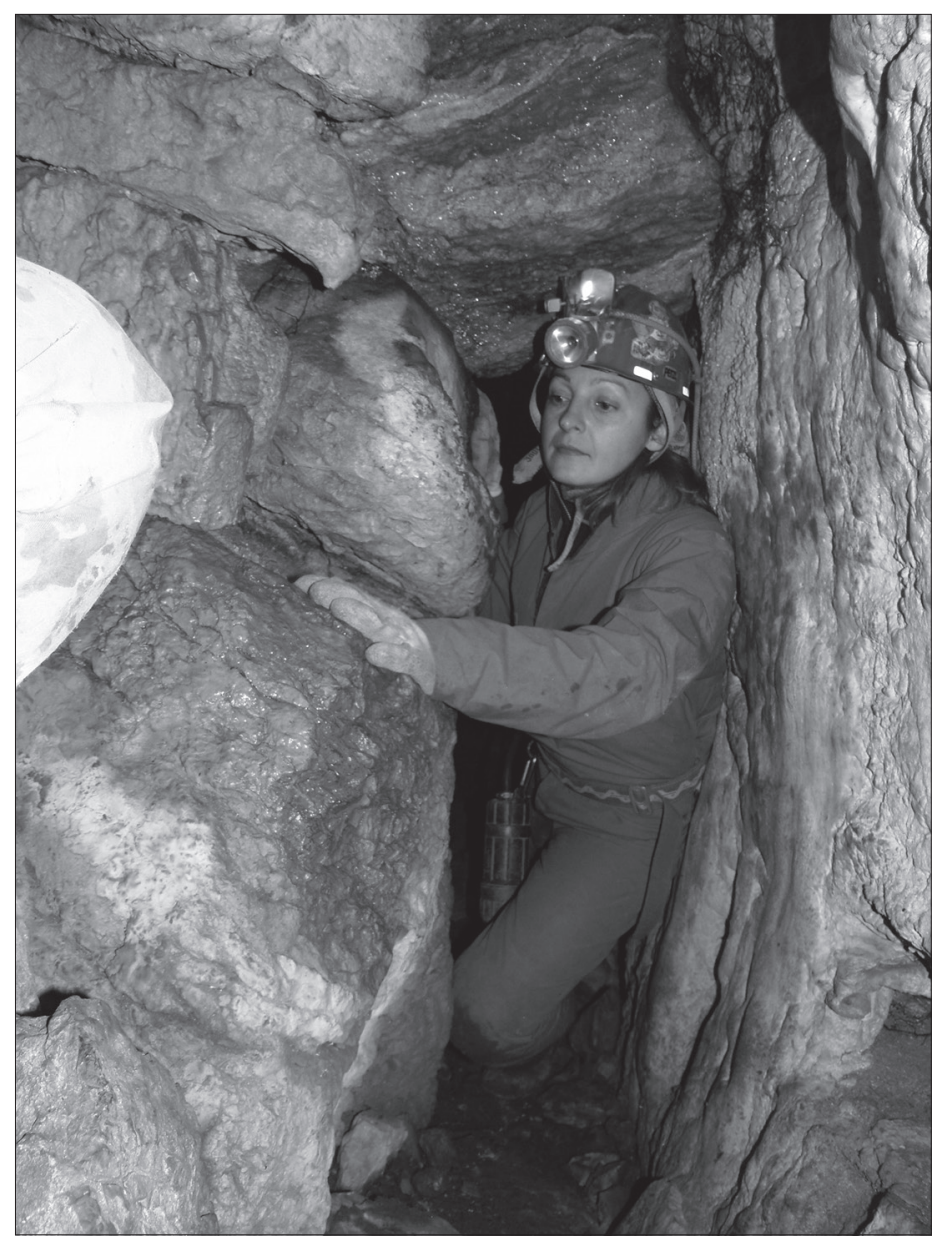

S1. 10. Najuži dio špilje Kalvarija na 4 m od ulaza kod oštrog zavoja u lijevo, foto: Vlado Božić, 2009.

nekada mogao zatvoriti vjerojatno kratkim kladama, kakve je jedino bilo moguće donijeti do zidova.

Bočna zapadna stijena stražarnice prekrivena je sigovinom, dok je istočna zasigana u gornjoj polovici. Sada je djelomično zasigana i sredina ovoga prvog zida.

Iza drugog zida prostire se prirodni dio špilje, i to $u$ duljini od još sedamdesetak metara s lijepim sigastim nakupinama. Prilikom izrade nacrta ulaznog dijela špilje sa zidovima posjećen je i lako prohodni dio špilje iza 
zidova. Ni u tlu ni na okolnim stijenama nisu tada nađeni tragovi boravka ljudi u tom dijelu špilje.

Nije poznato tko ju je gradio ni tko je i kada pokušao rušiti spominjane zidove.

Špilju su istraživali članovi DDISKF-a od 10. do 13. rujna 2009. godine i tom prilikom izradili speleološki nacrt cijele špilje ${ }^{11}$, a 25. studenoga 2009. članovi SD "Ursus spelaeus" i SO HPD "Željezničar" detaljno su snimili dio špilje sa zidovima. ${ }^{12}$ Naknadno su špilju 7. studenoga 2012. istraživali članovi SK "Ursus spelaeus" i ponovno snimili nacrt špilje.

\section{Zaključak}

O stanovništvu okolice utvrde Bužim iz toga doba nema nikakvih podataka. Za pretpostaviti je da su i ti stanovnici dobro pratili stanje na bojištu i pokušali navrijeme stvoriti utočište gdje bi se mogli skloniti kad dođu Osmanlije.

Najvjerojatnije je da su ljudi u okolnim špiljama sagradili obrambene zidove možda desetak godina prije dolaska Osmanlija, kada još nisu bili ometani borbama. Međutim, kako su Osmanlije napredovale prema zapadu Like pljačkajući i ubijajući, stanovništvo je počelo napuštati Liku, seleći u sigurnije krajeve prema sjeveru Hrvatske. Tako se dogodilo da nije više bilo stanovništva u okolici kada su Osmanlije zauzele cijelu Liku, pa i Bužim. Zbog toga u špiljama, u kojima su sagrađeni zidovi, nema dokaza boravka ljudi. Podzemne su utvrde tako ostale neiskorištene. Do takva se zaključka došlo tek nakon izrade nacrta i proučavanja dijela špilje iza sagrađenih zidova.

Svakako bi bilo dobro da povjesničari potraže pismene dokumente o ovomu razdoblju, a arheolozi u špiljama obave standardna arheološka iskapanja $\mathrm{i}$ istraživanja.

\section{Literatura}

Vlado BOŽIĆ, Utvrđene špilje u Lici, Speleolog, 57, Zagreb, 2009, 138-140.

Sanja GRKOVIĆ, Fotografija u službi zaštite kulturne baštine, Zagreb, 2007.

Dragutin HIRC, Lika i Plitvička jezera, Zagreb, 1900.

Zorislav HORVAT, Burgologija, srednjevjekovni utvrdeni gradovi kontinentalne Hrvatske, Zagreb, 2014.

11 T. KOVAČEVIĆ - A. KOVAČEVIĆ - M. PRPIĆ - D. PAVELIĆ, 2009, 21-22.

12 V. BOŽIĆ, 2010, 138-139. 
Tihomir KOVAČEVIĆ - Alan KOVAČEVIĆ - Marijan PRPIĆ - Damir PAVELIĆ, Špilje u funkciji čovjeka - Bužimska Kalvarija i Burzina tamnica (film). Knjiga sažetaka, 10. skup speleologa Hrvatske, Poreč, jama Baredine, 2009, 21-22.

Ivan KUKULJEVIĆ SAKCINSKI, Njeke gradine i gradovi u Kraljevini Hrvatskoj, Zagreb, 1869-1870.

Željko MATAIJA, Podzemna veza Vrbasa i Bužimčice - Skriveni svijet pred značajnim otkrićem u jami blizu

Tesline kuće, Večernji list, 27. 9. 2006.

\section{Internetski izvori}

Krešimir MATIJEVIĆ, Utvrđeni gradovi srednjovjekovne Like (9. rujna 2017.), https:// darkoantolkovic.wordpress.com/2017/02/09/utvrdeni-gradovi-srednjovjekovnelike/ (21. studenoga 2018.)

Nastavak istraživanja u Budimu (18. rujna 2009),

http://www.ddiskf.hr/hr/aktivnosti/44-zapisi-sa-manjih-istraivanja/75-nastavakistraivanja-u-buimu (20. studenoga 2018.)

Dorotea PEROVIĆ, Kalvarija - pravi mali biser obrambene arhitekture (3. rujna 2015.), http://radio.hrt.hr/clanak/kalvarija-pravi-mali-biser-obrambene-arhitekture/100556/

(20. studenoga 2018.)

\section{BUŽIM UNDERGROUND FORTIFICATIONS}

\section{Summary}

Bužim is a municipality 15 kilometres northwest of Gospić, whose territory is mentioned in literature from the $11^{\text {th }}$ century. In its centre there are now the remains of a fort about which there is no accurate data of when it was built, but it is known that it was ruled by renowned aristocrats of Lika until the arrival of the Ottomans in Lika in the $16^{\text {th }}$ century. Likewise as elsewhere in Croatia people who tried to save themselves from the invaders by hiding in mountains and caves who for the sake of defence built underground fortifications.

In the Bužim region speleologists have explored the Vrbas cave, the Špilja cave under the fort and the Kalvarija cave. Unfortunately, historians and archaeologists have not researched the caves and so, for now, all exists is the data from the speleologists gathered in their speleological exploration. A particular feature of these caves is the construction work inside them, in other words, the construction of the walls which prevented unwanted people from breaching into the deeper part of the cave.

Keywords: Bužim, underground fortifications, cave 